\title{
MANAJEMEN KEUANGAN PEMERINTAH DAERAH KABUPATEN TABANAN
}

\section{Kadek Arta Wijaya Santosa ${ }^{1}$ Gede Mertha Sudiartha ${ }^{2}$}

\author{
${ }^{1,2}$ Fakultas Ekonomi dan Bisnis Universitas Udayana, Bali, Indonesia \\ email: arta97885@gmail.com
}

\begin{abstract}
ABSTRAK
Penelitian ini bertujuan untuk mengetahui dan menganalisis bagaimanakah pengelolaan keuangan daerah serta perbandingan antara anggaran dan realisasi terhadap kinerja pemerintah daerah di Kabupaten Tabanan. Penelitian ini dilakukan di pemerintah daerah Kabupaten Tabanan. Pengumpulan data menggunakan metode wawancara dan observasi non partisipan dengan teknik analisis yang digunakan adalah deskriptif kualitatif. Hasil penelitian menunjukkan bahwa manajemen keuangan pemerintah daerah di Kabupaten Tabanan telah mengacu kepada Permendagri No. 13 Tahun 2006 dan laporan kinerja pemerintah daerahnya dalam lima tahun terakhir jika di rata-ratakan pemda Kabupaten Tabanan telah memperoleh predikat B, walaupun pada tahun 2014 dan 2015 memperoleh nilai SAKIP dengan predikat C. Perbandingan antara anggaran dan realisasi pendapatan daerah terhadap kinerja pemerintah daerah di Kabupaten Tabanan menunjukkan bahwa apabila anggarannya lebih besar dibandingkan realisasinya yang disebabkan oleh beberapa komponen pada tahun dan sebaliknya, apabila anggaran lebih kecil dibandingkan realisasinya yang dimana selisih tersebut tersebut dapat menjadi sumber-sumber SiLPA untuk pembiayaan investasi dalam APBD. Belanja daerah dalam kurun waktu lima tahun terakhir menunjukkan bahwa realisasinya lebih kecil dibandingkan anggarannya yang dimana menjadi sumber-sumber SiLPA dan sudah melakukan efisiensi.
\end{abstract}

Kata kunci: pengelolaan keuangan daerah, anggaran dan realisasi, kinerja pemerintah daerah

\begin{abstract}
This study aims to find out and analyze how regional financial management and comparison between budget and realization of the performance of local governments in Tabanan Regency. This research was conducted in the local government of Tabanan Regency. Data collection using interview methods and non-participant observation with the analysis technique used is descriptive qualitative. The results showed that local government financial management in Tabanan Regency had referred to Permendagri No. 13 of 2006 and local government performance reports in the last five years, if on average the Tabanan regency government has received the title B, even though in 2014 and 2015 it received the SAKIP score with the title $C$. Comparison between the budget and the realization of local revenue to the performance of local governments in Tabanan Regency shows that if the budget is greater than the realization caused by several components in the year and vice versa, if the budget is smaller than the realization where the difference can be sources of SiLPA for investment financing in the APBD. Regional expenditure in the last five years shows that the realization is smaller than the budget which is a source of SiLPA and has been efficient.

Keywords: regional financial management, budgeting and realization, local government performance
\end{abstract}




\section{PENDAHULUAN}

Tantangan dan permasalahan dalam pengelolaan pemerintah daerah disebabkan banyaknya peraturan dan ketentuan yang sulit diimplementasikan atau bermulti tafsir (BPKP, 2008). Hal tersebut tercermin dari : 1) RPJP Nasional yang merupakan dokumen abstrak yang tidak bersifat operasional dan sulit ditarik benang merahnya ke RPJPD, RPJMD dan RKPD, 2) Sistem dan Prosedur Akuntansi diatur oleh Depdagri dengan mendasarkan pada PP No. 24 Tahun 2005 tentang Standar Akuntansi Pemerintahan, yang menjadikan Pemerintah daerah tidak mempunyai keleluasaan dalam membuat pencatatan dan pelaporan hasil kegiatan, 3) Banyaknya daerah yang tidak tepat waktu dalam penetapan APBD sebagai akibat dari keterlambatan membuat pedoman penyusunan APBD dan terlambat diterimanya informasi dana dari pemerintah yang lebih tinggi, 4) Pada penatausahaan keuangan daerah terdapat kekurang tegasan peraturan tentang pengelolaan asset daerah, khususnya dalam penghitungan nilai asset. Hal ini berdampak pada pemerintah daerah sebagai pihak yang memiliki peran dalam mengelola keuangan daerah terutama dalam menggali dan menghasilkan sumbersumber keuangan untuk mengupayakan pertumbuhan pendapatan daerah (Antari dan Sedana, 2018).

Selain itu permasalahan yang dihadapi pemerintah daerah adalah system informasi yang belum optimal dan keterbatasan kuantitas dan kualitas sumber daya manusia akuntansi pemerintah daerah sehingga sulit menghasilkan laporan keuangan dan kinerja dengan baik. Untuk itu diperlukan alternatif berupa rekruitment sumber daya manusia yang kompeten dan pengembangan Sistem Informasi Manajemen Keuangan Daerah (SIMDA) yang memadai. Hal ini didukung oleh riset Rondonuwu dkk. (2015) bahwa kemampuan pemerintah daerah dalam mengelola keuangan daerahnya tercermin pada peningkatan penerimaan pendapatan daerah, kemampuan membiayai pembangunan daerah dan pelayanan sosial kepada masyarakat. Pengelolaan keuangan yang dilakukan secara efisien dan efektif akan dapat menghasilkan kinerja yang optimal, namun bilamana terjadi kesenjangan antara target dan realisasi penerimaan daerah, sehingga dapat menimbulkan permasalahan terkait dengan anggaran pembiayaan pembangunan daerah (Manopo dkk., 2015). Eton et al. (2019) berpendapat bahwa anggaran adalah rencana keuangan serta daftar dari semua pengeluaran dan pendapatan yang telah direncanakan. Setiap anggaran memberikan informasi mengenai program kerja/kegiatan yang hendak dilakukan dalam beberapa periode yang akan datang (Mardiasmo, 2009) Anggaran dibuat untuk merencanakan berkaitan dengan tindakan yang akan dilakukan, besaran biaya yang dibutuhkan, serta target hasil yang akan diperoleh dari belanja pemerintah (Halim, 2016:93).

Pertumbuhan penerimaan pendapatan asli daerah ditentukan oleh kemampuan daerah tersebut dalam menggali potensi-potensi daerah sebagai sumber pendapatan. Potensi-potensi yang dimiliki setiap daerah diharapkan agar mampu dimanfaatkan dengan baik sehingga sumber keuangan yang bersumber dari pendapatan asli daerah dapat terus meningkat (Taras dan Artini, 2017). Pernyataan tersebut sesuai dengan hasil penelitian yang dilakukan oleh Sumawan dan Sukarta (2016) yang berpendapat bahwa peningkatan penerimaan pendapatan asli daerah yang tinggi setiap tahunnya menunjukkan bahwa tingginya sumber keuangan yang 
dimiliki oleh daerah. Besar kecilnya potensi daerah akan dapat mempengaruhi tingkat penerimaan pendapatan asli daerah tersebut. Apabila pendapatan di suatu daerah tinggi maka belanja untuk memenuhi kebutuhan daerahnya juga semakin tinggi (Sari dan Mustanda, 2019). Mohammed and Salihu (2015) menyatakan bahwa belanja daerah juga dapat dibedakan menjadi dua, yaitu belanja modal dan belanja rutin. Dalam konteks manajemen keuangan daerah, belanja rutin memberikan manfaat ekonomi kurang dari satu tahun, sementara belanja modal memberikan manfaat lebih satu tahun untuk memperoleh atau meningkatkan aset tetap. Hal senada diungkapkan oleh (Mahmudi, 2010:82) bahwa manajemen belanja daerah menjadi fokus pemerintah daerah untuk mengoptimalisasikan manajemen keuangan daerah.

Pemerintah Provinsi Bali juga dihadapkan pada permasalahan yang sama seperti pengelolaan keuangan pemerintah daerah lainya di Indonesia. Permasalahan pemerintah daerah di Bali juga terkait dengan: (1) ketidakmampuan dan ketidakleluasaan dalam membuat pencatatan dan pelaporan hasil kegiatan; (2) ketidaktepatan waktu dalam penetapan APBD sebagai akibat dari keterlambatan membuat pedoman penyusunan APBD; (3) ketidak-mampuan dalam penghitungan nilai asset daerah sebagai sumber anggaran pembiayaan pemerintahan daerah. Dari hasil perhitungan rasio pertumbuhan pendapatan kabupaten/kota di Bali ditunjukan bahwa rata-rata rasio pertumbuhan terendah diperoleh kabupaten Tabanan dan Denpasar dengan rasio sebesar 8,43 persen dan 6,56 persen. Dari dua kabupaten tersebut kabupaten Tabanan memiliki nilai potensi lebih besar daripada Kota Denpasar. Selain itu masih terdapat kesalahan penganggaran belanja dan penatausahaan aset tetap belum tertib, terdapat pengelolaan pendapatan dan pengelolaan belanja daerah yang tidak sesuai ketentuan. Berdasarkan sumber berita bali.com (2018) disebutkan bahwa kabupaten Tabanan belum maksimal dalam membangun potensi daerahnya sehingga menimbulkan defisit anggaran sebagai sumber pembiayaan pemerintahan. Untuk itu diperlukan kajian penelitian terkait manajemen keuangan pemerintah daerah.

Berdasarkan uraian latar belakang yang telah dipaparkan sebelumnya, maka rumusan masalah dalam penelitian ini yaitu: 1) Bagaimanakah Pengelolaan Keuangan Pemerintah Daerah di Kabupaten Tabanan? 2) Bagaimanakah perbandingan antara Anggaran dan Realisasi pendapatan dan belanja daerah terhadap kinerja Pemerintah Daerah di Kabupaten Tabanan?. Berdasarkan rumusan masalah yang sudah dipaparkan sebelumnya, maka tujuan dari penelitian ini yaitu: 1) Untuk mengetahui dan menganalisis bagaimanakah pengelolaan keuangan Pemerintah Daerah di Kabupaten Tabanan. 2) Untuk mengetahui dan menganalisis bagaimanakah perbandingan antara Anggaran dan Realisasi pendapatan dan belanja daerah terhadap kinerja Pemerintah Daerah di Kabupaten Tabanan. Kegunaan teoretis yang didapatkan dari penelitian ini yaitu diharapkan dapat memberikan kontribusi teoretis berupa bukti empiris untuk pengembangan ilmu pengetahuan manajemen keuangan pemerintah. Kegunaan praktis yang didapatkan melalui penelitian ini diharapkan dapat dijadikan informasi serta masukan bagi pemerintah daerah Kabupaten Tabanan dalam melakukan pengelolaan keuangan terkait pengelolaan pendapatan dan belanja daerah. 
Pengelolaan keuangan pemerintah daerah merupakan keseluruhan dari suatu kegiatan yang meliputi perencanaan, penatausahaan, pelaporan, pertanggungjawaban serta pengawasan keuangan daerah (Halim, 2007:330). Pengelolaan keuangan pemerintah daerah pada umumnya didominasi oleh kelangkaan sumber daya keuangan karena pemerintah daerah merupakan organisasi nirlaba dan memiliki peluang terbatas dalam menghasilkan pendapatan, akan tetapi pemerintah daerah juga dihadapkan dengan agenda program dan kegiatan yang semakin meningkat sehingga pendapatan yang telah dihasilkan dapat digunakan (Mutya dan Josephine, 2018).

Menurut Permendagri Nomor 13 Tahun 2006 tentang Pedoman Pengelolaan Keuangan Daerah menjelaskan bahwa keuangan pemerintah daerah merupakan semua hak dan kewajiban yang dimiliki suatu daerah dalam rangka penyelenggaraan kegiatan pemerintah daerah yang dapat dinilai dengan uang termasuk segala bentuk kekayaan yang berhubungan dengan hak dan kewajiban daerah tersebut. Hal ini didukung oleh riset Ritonga (2014) yang menyatakan bahwa pelaksanaan suatu program atau kegiatan pemerintah daerah dibiayai oleh anggaran pemerintah daerah itu sendiri. Keuangan pemerintah daerah terdiri dari dua jenis, yaitu penerimaan dan pengeluaran daerah. Menurut Undang-Undang Nomor 32 tahun 2004 tentang pemerintah daerah terdapat sumber-sumber pendapatan dan penerimaan daerah terdiri dari PAD, Dana Perimbangan, dan LainLain Pendapatan Daerah yang Sah.

Menurut Undang-Undang Nomor 25 Tahun 1999 tentang Perimbangan Keuangan antara Pemerintah Pusat dan Daerah, menjelaskan bahwa pendapatan asli daerah merupakan penerimaan yang diperoleh dari sumber-sumber dalam wilayahnya sendiri, yang dipungut berdasarkan peraturan daerah dengan peraturan perundang-undangan yang berlaku. Kemampuan menggali serta memanfaatkan potensi-potensi yang dimiliki daerah secara optimal akan mampu menghasilkan sumber-sumber keuangan yang berasal dari pendapatan asli daerah (Sebastian dan Cahyo, 2016). Penelitian yang dilakukan oleh Budianto dan Alexander (2016) di pemerintah Kabupaten/Kota Provinsi Sulawesi Utara menunjukkan bahwa semakin besar pendapatan asli daerah, maka semakin baik kinerja keuangan daerah sesuai dengan prinsip-prinsip otonomi daerah yang akan mengakibatkan peningkatan kinerja pemerintah daerah. Hal senada juga diungkapkan oleh hasil riset Bambang dan Farhan (2016), Sunaryo dan Ghofar (2015), Kondo (2015), serta Ichsan et al. (2018) yang menyatakan bahwa semakin besar pendapatan asli daerah, maka semakin baik kinerja keuangan daerah yang berdampak pada peningkatan kinerja pemerintah daerah.

Menurut UU No. 25 Tahun 1999 dan UU No. 33/2004 dana perimbangan adalah pendapatan daerah yang bersumber dari APBN yang terdiri dari Dana Bagi Hasil (DBH), Dana Alokasi Umum (DAU), dan Dana Alokasi Khusus (DAK). Selain dimaksudkan untuk membantu daerah dalam mendanai pembangunan, dana perimbangan juga bertujuan untuk mengurangi ketimpangan sumber pendanaan pemerintahan antara pusat dan daerah. Apabila realisasi belanja daerah lebih besar daripada pendapatan daerah maka akan terjadi defisit. Dalam mengatasi hal tersebut maka pemerintah pusat mentransfer dana dalam bentuk dana perimbangan kepada pemerintah daerah. Semakin besar transfer dana perimbangan yang diterima 
pemerintah pusat akan menunjukkan semakin kuat ketergantungan pemerintah daerah terhadap pemerintah pusat dalam memenuhi kebutuhan daerahnya, sehingga akan membuat kinerja daerah menjadi menurun (Andirfa dkk., 2016). Hal senada juga diungkapkan oleh hasil riset Armaja dkk., (2015), Hendawati et al. (2018), Oktaviana dan Husnan (2017), Kurniawati et al. (2017), serta Tarmizi et al. (2015) yang menyatakan bahwa Semakin besar transfer dana perimbangan yang diterima pemerintah pusat maka akan membuat kinerja pemerintah daerah menjadi menurun. Menurut Undang-Undang Nomor 33 Tahun 2004 tentang Perimbangan Keuangan antara Pemerintah Pusat dan Daerah menjelaskan bahwa lain-lain pendapatan daerah yang sah terdiri dari hibah serta dana darurat.

Pengeluaran daerah terdiri dari belanja daerah dan pembiayaan daerah. Belanja daerah dibagi menjadi dua jenis yaitu belanja tidak langsung dan belanja langsung. Belanja tidak langsung terdiri dari belanja pegawai, belanja bunga, belanja subsidi, belanja hibah, belanja bantuan sosial, belanja bagi hasil, belanja bantuan keuangan, serta belanja tidak terduga. Belanja subsidi serta bantuan sosial merupakan prioritas kegiatan pemerintah sebagai upaya memberikan pelayanan dan kepuasan masyarakat. Sedangkan belanja langsung sendiri terdiri dari honorarium/upah, belanja barang dan jasa serta belanja modal. Sementara itu pembiayaan daerah sendiri meliputi semua transaksi keuangan yang digunakan untuk menutupi defisit atau untuk memanfaatkan surplus. Riset sejenis dilakukan oleh Wardhani et al. (2017) dinyatakan pengeluaran pemerintah di Indonesia tidak efisien dan dapat meningkatkan kinerja, sebaliknya antara pengeluaran pemerintah memiliki hubungan negatif dengan kinerja pemerintah daerah. Pengeluaran pemerintah daerah diukur dari total belanja rutin serta belanja pembangunan yang telah dialokasikan dalam anggaran daerah (Rahman dkk., 2016).

Menurut Undang-Undang Nomor 25 Tahun 1999 tentang Perimbangan Keuangan antara Pemerintah Pusat dan Daerah menjelaskan bahwa Anggaran Pendapatan dan Belanja Daerah merupakan suatu rencana keuangan tahunan daerah yang ditetapkan berdasarkan Peraturan Daerah mengenai Anggaran Pendapatan Belanja Daerah. Kuntari et al. (2019) menyatakan bahwa anggaran pemerintah daerah merupakan rencana untuk kegiatan pemerintah daerah serta alokasi sumber daya. Anggaran pada setiap tingkat pemerintahan dipandang sebagai alat yang membantu dalam menghitung dan memenuhi biaya yang terkait dengan fasilitas sosial (Usman et al., 2016).

Berdasarkan kajian teoritis dan empiris yang telah dipaparkan sebelumnya maka agar lebih memperjelas arah dari penelitian ini maka dibuat kerangka berpikir yang dapat dilihat pada Gambar 1. berikut ini.

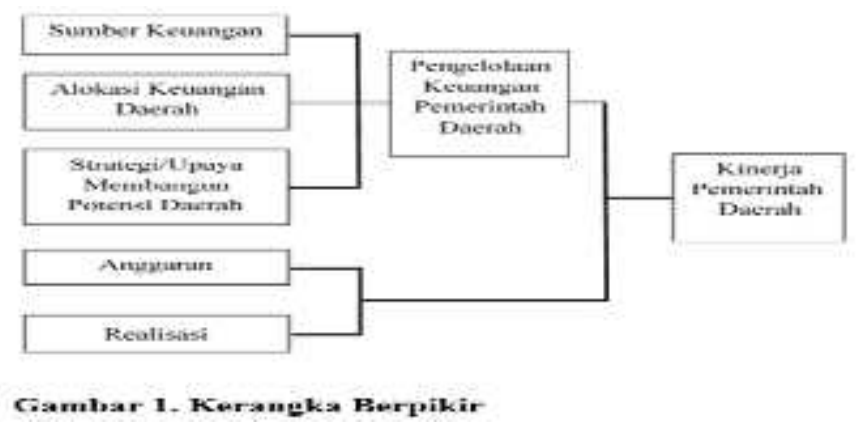




\section{METODE PENELITIAN}

Penelitian ini menggunakan pendekatan kualitatif bersifat deskriptif yang bertujuan untuk mendeskripsikan atau menggambarkan data yang telah terkumpul dalam bentuk narasi. Lokasi pada penelitian ini adalah di Pemerintah Daerah Kabupaten Tabanan. Obyek dalam penelitian ini adalah manajemen keuangan pemerintah daerah Kabupaten Tabanan.

Penelitian ini menggunakan jenis data kuantitatif berupa data Laporan Realisasi Anggaran (LRA) yang diolah dan dipublikasikan oleh organisasi / instansi terkait. Data yang digunakan dalam penelitian ini berupa data primer dan sekunder. Dimana data primer dari hasil wawancara langsung dengan pihak pengelola keuangan pemerintah daerah sedangkan data sekunder yang digunakan dalam penelitian ini adalah Laporan Realisasi Anggaran Pendapatan dan Belanja Daerah Kabupaten Tabanan yang bersumber dari laporan Statistik Keuangan Pemerintah Daerah Kabupaten Tabanan.

Populasi dalam penelitian ini adalah seluruh pegawai di Badan Keuangan Daerah Kabupaten Tabanan. Sampel yang digunakan dalam penelitian ini adalah Kepala Bidang Penganggaran, Kepala Bidang Akuntansi, Kepala Bidang Perbendaharaan, Kepala Sub Bagian Perencanaan, dan Kepala Sub Bidang Perencanaan Anggaran. Metode penentuan sampel menggunakan non probability sampling dengan teknik purposive sampling, yaitu sampel yang ditentukan dengan pertimbangan tertentu. Kriteria sampel dalam penelitian ini adalah pegawai yang memiliki wewenang dalam memberikan informasi mengenai pengelolaan keuangan pemerintah daerah di Kabupaten Tabanan. Pengumpulan data menggunakan metode wawancara yang dilakukan langsung dengan pihak pengelola keuangan pemerintah daerah dan observasi non partisipan yang dilakukan dengan cara melakukan observasi pada Laporan Realisasi Anggaran Pendapatan dan Belanja Daerah Kabupaten Tabanan.

Data dianalisis dengan menggunakan teknik analisis deskriptif kualitatif. Deskriptif merupakan suatu metode dalam meneliti status sekelompok manusia, suatu objek, suatu set kondisi, suatu sistem pemikiran ataupun suatu kelas peristiwa pada masa sekarang (Nazir, 1988:63). Penelitian kualitatif merupakan penelitian tentang riset yang bersifat menjelaskan dan cenderung menggunakan analisis. Deskriptif kualititaf adalah suatu metode dalam meneliti status sekelompok manusia, suatu objek, suatu set kondisi, suatu sistem pemikiran ataupun suatu kelas peristiwa pada masa sekarang yang bersifat menjelaskan dan cenderung menggunakan analisis untuk memberikan makna dan informasi.

\section{HASIL DAN PEMBAHASAN}

Tabanan merupakan salah satu daerah di Provinsi Bali yang memiliki ibukota yaitu Tabanan. Luas wilayah Kabupaten Tabanan seluas $839,93 \mathrm{~km}^{2}$ dari luas wilayah Provinsi Bali. Kabupaten Tabanan dipimpin oleh Bupati sebagai pemegang jabatan tertinggi di daerah tersebut. Secara administratif Kabupaten Tabanan terbagi menjadi 10 (sepuluh) wilayah kecamatan yaitu Baturiti, Kediri, Kerambitan, Marga, Penebel, Pupuan, Selemadeg, Selemadeg Barat, Selemadeg Timur, dan Tabanan. 
Dengan ditetapkannya Permendagri Nomor 13 Tahun 2006 Tentang Pedoman Pengelolaan Keuangan Daerah, maka dalam rangka mewujudkan akuntabilitas serta transparansi di lingkungan pemerintah daerah untuk menyusun perencanaan pengelolaan keuangan daerah melalui Rencana Kerja dan Anggaran (RKA) dan Dokumen Pelaksana Anggaran (DPA) Satuan Kerja Perangkat Daerah. Rencana Kerja dan Anggaran SKPD merupakan dokumen perencanaan dan penganggaran yang berisi rencana pendapatan, rencana belanja program dan kegiatan SKPD serta rencana pembiayaan sebagai dasar penyusunan APBD. Selain itu, pemerintah daerah juga perlu memperhatikan bagaimana strategi atau upaya yang perlu dilakukan dalam membangun potensi yang dimiliki daerahnya.

Dalam Undang-Undang Nomor 17 Tahun 2003 Tentang Keuangan Negara menegaskan bahwa Laporan Pertanggungjawaban Keuangan yang dimaksud dinyatakan ke dalam bentuk laporan keuangan yang setidak-tidaknya meliputi Laporan Realisasi Anggaran, Neraca, Laporan Arus Kas, Catatan atas Laporan Keuangan, dan disusun berdasarkan SAP. Berdasarkan sumber berita ptpalembang.go.id (2019) disebutkan bahwa Laporan Realisasi Anggaran meberikan gambaran perbandingan antara Daftar Isian Pelaksanaan Anggaran (DIPA) dengan realisasinya, yang meliputi unsur-unsur pendapatan dan belanja dalam tahun yang bersangkutan.

Analisis yang dilakukan dalam penelitian ini digunakan untuk mengetahui proses pengelolaan keuangan pemerintah daerah Kabupaten Tabanan yang dimulai dari penyusunan anggaran dengan cara mendeskripsikan atau menggambarkan keadaan nyata yang terjadi, mengamati dengan bertitik tolak pada pemahaman konsepsi dan pandangan atas teori-teori terkait (Fitrie, 2008).

Untuk mengimplementasikan Permendagri Nomor 13 Tahun 2006 tersebut, khususnya yang terkait dalam Siklus Pengelolaan Keuangan Daerah adalah sebagai berikut.

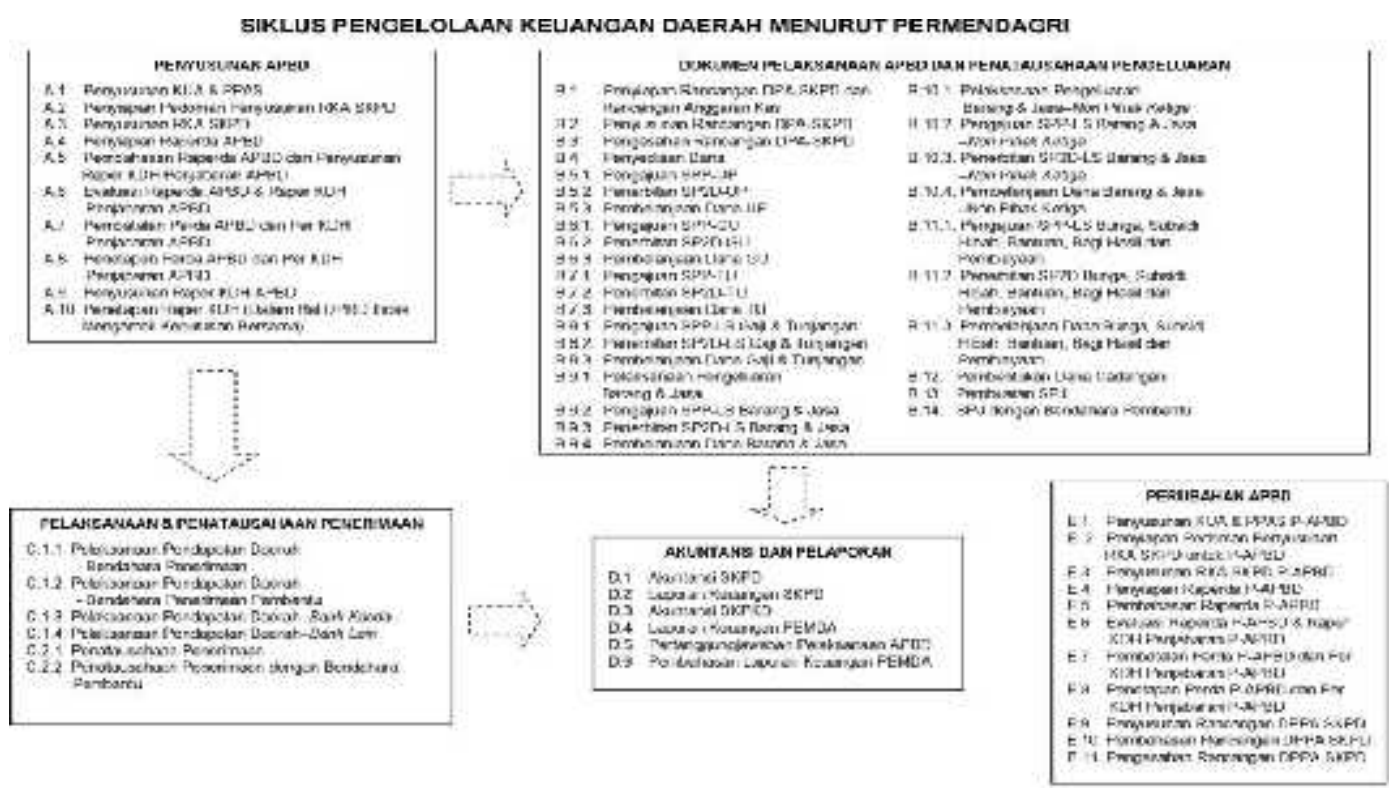

Gambar 2. Siklus Pengelolaan Keuangan Daerah Menurut Permendagri

Sumber: Permendagri No. 13 Tahun 2006, 2019 
Proses penyusunan APBD dimulai dari bulan Januari melalui musyawarah perencanaan pembangunan (Musrenbang) yang dilakukan pada setiap kecamatan dengan melibatkan pemerintah desa dan masyarakat. Dalam Musrenbang tersebut dilakukan mapping terkait adanya usulan dari masyarakat sehingga dibuatkan berita acara Musrenbang. Berita acara Musrenbang tersebut selanjutnya akan disampaikan kepada Organisasi Perangkat Daerah (OPD) yang nantinya akan menjadi kegiatan Organisasi Perangkat Daerah. Berdasarkan kegiatan Organisasi Perangkat Daerah (OPD) tersebut pemerintah daerah melakukan forum OPD, dimana dalam forum OPD itulah selanjutnya menjadi Rencana Kerja Pemerintah Daerah (RKPD).

Penyusunan Rancangan RKPD paling lambat dilakukan minggu pertama bulan April, dimana dalam RKPD tersebut terdapat asumsi penerimaan dan pengeluaran. Penerimaan akan menggunakan asumsi jika dalam RKPD tersebut semuanya dilakukan perhitungan sesuai dengan Rencana Pembangunan Jangka Menengah Daerah (RPJMD). Asumsi penerimaan RPJMD dihitung dari seberapa besar target penerimaan tersebut meningkat sehingga berdasarkan asumsi penerimaan tersebut barulah bisa memasukkan belanja, dimana nantinya antara penerimaan dan belanja tersebut akan terjadi balance di dalam Rencana Kerja Pemerintah Daerah (RKPD). Setelah RKPD ditetapkan selanjutnya dilakukan Penyusunan Kebijakan Umum Anggaran (KUA) serta Proiritas dan Plafon Anggaran Sementara (PPAS).

Penyusunan Kebijakan Umum Anggaran (KUA) serta Proiritas dan Plafon Anggaran Sementara (PPAS) mengacu kepada peraturan perundang-undangan tentang pendapatan khususnya Pendapatan Asli Daerah (PAD) yang berdasarkan potensi riil PAD, sedangkan Dana Perimbangan yang berasal dari pemerintah pusat, provinsi, kabupaten/kota lainnya tersebut mengacu pada pemerintah itu sendiri. Apabila platform tersebut belum turun pemerintah daerah akan mengacu pada anggaran tahun sebelumnya khusus untuk Dana Perimbangan. Dari RKPD yang turunannya menjadi KUA dan PPAS tersebut terdapat potensi penerimaan itu turun dikarenakan pada RKPD yang awalnya berdasarkan asumsi, sedangkan pada KUA dan PPAS berdasarkan potensi riil sehingga terjadi potensi penerimaan itu turun, dimana secara otomatis belanjanya juga turun karena pendapatan atau penerimaannya turun.

Selain pendapatan tersebut masih terdapat pendapatan daerah lainnya, dimana menurut Kepala Bidang Akuntansi Kabupaten Tabanan adalah sebagai berikut:

"Selain PAD dan Dana Perimbangan, masih terdapat pendapatan lainnya yaitu Lain-Lain Pendapatan Daerah Yang Sah seperti pendapatan hibah dan Penerimaan Pembiayaan seperti penggunaan SiLPA, pinjaman dalam negeri dan penerimaan kembali investasi non permanen lainnya. Sumber-sumber keuangan atau pendapatan tersebut meliputi semua penerimaan uang melalui rekening Kas Umum Daerah dan penerimaan lainnya yang sesuai dengan ketentuan peraturan perundang-undangan."

Hasil kesepakatan KUA dan PPAS disepakati paling lambat minggu kedua bulan Agustus agar pemerintah daerah dapat menyusun rancangan APBD. Rancangan APBD tersebut selanjutnya ditindaklanjuti dengan dikeluarkannya Surat Edaran Bupati tentang penyusunan Rencana Kerja dan Anggaran Satuan Kerja Perangkat Daerah (RKA-SKPD). Satuan Kerja Perangkat Daerah menyusun 
RKA berdasarkan KUA PPAS yang telah disepakati dan Surat Edaran Bupati, dimana dari hasil RKA tersebut barulah disusun rancangan APBD. Berdasarkan rancangan APBD tersebut selanjutnya akan dibahas oleh Tim Anggaran Pemerintah Daerah (TAPD), setelah pembahasan tersebut disetujui maka selanjutnya rancangan APBD tersebut akan disampaikan ke DPRD untuk dibahas kembali bersama Kepala Daerah paling lambat akhir november rancangan APBD tersebut sudah disepakati.

Hasil kesepakatan dari rancangan APBD selanjutnya disampaikan kepada Gubernur untuk dievaluasi 3 hari kerja setelah persetujuan bersama. Gubernur memiliki waktu 15 hari kerja untuk melakukan evaluasi terhadap rancangan APBD tersebut. Hasil dari evaluasi tersebut nantinya akan dilakukan penyempurnaan oleh DPRD dan TAPD. Berdasarkan hasil penyempurnaan tersebut kepala daerah menetapkan perda tentang APBD dan penjabaran tentang APBD dilakukan paling lambat 31 Desember tahun sebelumnya.

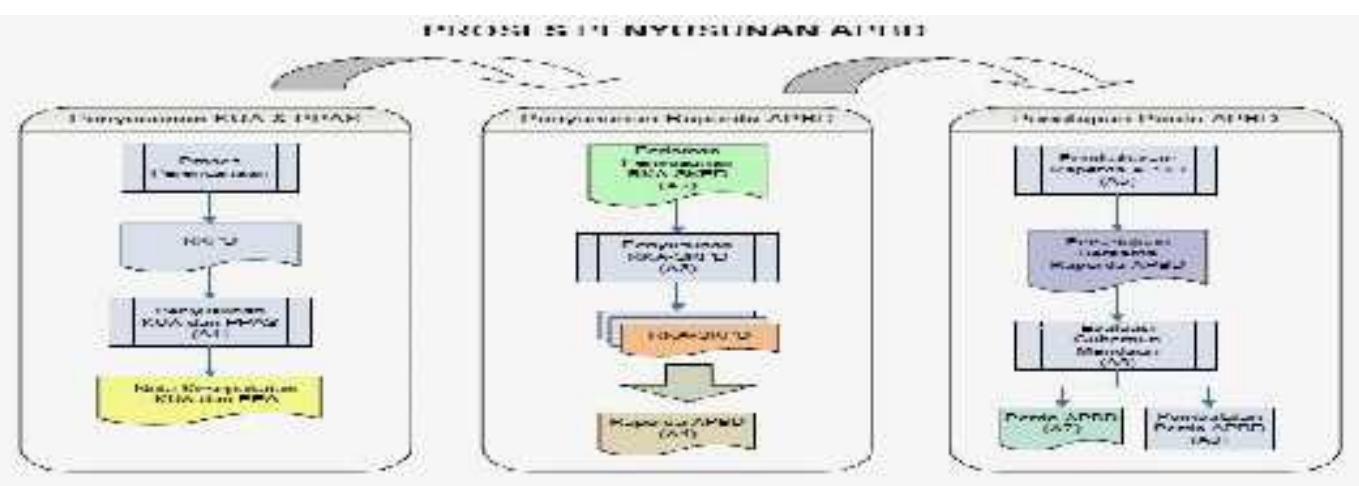

Gambar 3. Proses Penyusunan APBD

Sumber: Permendagri No. 13 Tahun 2006, 2019

Setelah dilakukannya penetapan APBD, Pejabat Pengelolaan Keuangan Daerah (PPKD) menyiapkan surat pemberitahuan tentang penyusunan Dokumen Pelaksana Anggaran sehingga Organisasi Perangkat Daerah (OPD) dapat menyusun rancangan DPA yang selanjutnya akan diajukan kepada Tim Anggaran Pemerintah Daerah (TAPD) untuk dibahas. Setelah rancangan DPA tersebut dibahas oleh TAPD maka selanjutnya hasil dari pembahasan tersebut akan disampaikan kepada Pejabat Pengelola Keuangan Daerah (PPKD) untuk disahkan yang kemudian pelaksanaannya nanti berdasarkan hasil pengesahan DPA tersebut. Pejabat Pengelola Keuangan Daerah (PPKD) kemudia menyiapkan Surat Penyediaan Dana (SPD) yang selanjutnya Organisasi Perangkat Daerah melakukan proses pengamprahan dengan mekanisme proses pencairan dana sesuai dengan jenis belanja atau rincian obyek belanja tersebut.

Alokasi belanja pemerintah daerah Kabupaten Tabanan menurut Kepala Bidang Perbendaharaan dan Kasubid Perencanaan Anggaran adalah sebagai berikut: "Alokasi belanja pemerintah daerah Kabupaten Tabanan terdiri dari belanja tidak langsung, belanja langsung, dan pengeluaran pembiayaan. Belanja tidak langsung terdiri dari belanja pegawai, belanja bunga, belanja hibah dan bantuan sosial, belanja bagi hasil kepada pemerintah desa, bantuan keuangan kepada pemerintah desa atau partai politik serta belanja tidak terduga. Selanjutnya ada 
belanja langsung yang terdiri dari belanja pegawai, belanja barang/jasa, dan belanja modal. Terkahir ada pengeluaran pembiayaan seperti penyertaan modal."

Selain alokasi belanja yang dilakukan oleh pemerintah daerah Kabupaten Tabanan, pemerintah daerah juga melakukan strategi atau upaya-upaya apa saja guna membangun potensi daerah yang dimiliki, dimana hal tersebut juga merupakan salah satu bagian dari pengelolaan keuangan pemerintah daerah sehingga akan berdampak terhadap kinerja pemerintah daerah Kabupaten Tabanan. Menurut Kasubag Perencanaan, strategi atau upaya yang diterapkan pemerintah daerah dalam membangaun potensi daerah Kabupaten Tabanan adalah sebagai berikut: "Upaya yang telah diterapkan oleh pemerintah daerah Kabupaten Tabanan adalah dengan meningkatkan kualitas SDM yang berkaitan dengan peningkatan potensi daerah, mengembangkan potensi daerah seperti agrowisata dan desa wisaya yang nantinya dapat meningkatkan pendapatan daerah, pemanfaatan teknologi informasi dan komunikasi guna memberikan layanan perpajakan sehingga mudah diakses oleh masyarakat serta melakukan pengawasan terhadap hal tersebut."

Setelah pelaksaan APBD sampai di akhir tahun maka selanjutnya pemerintah daerah akan membuat laporan pertanggunjawaban pelaksanaan APBD. Laporan pertanggunjawaban pelaksanaan APBD dimulai dari adanya pemeriksaan dari aparat pemeriksa seperti BPK. Berdasarkan pemeriksaan tersebut pemerintah daerah juga akan mengajukan perda tentang laporan pertanggunjawaban pelaksanaan APBD kepada DPRD untuk dibahas. Setelah pembahasan tersebut disepakati bersama maka selanjutnya hasil pembahasan tersebut akan disampaikan kepada Gubernur untuk di evaluasi. Hasil dari evaluasi tersebut nantinya akan dilakukan penyempurnaan oleh DPRD dan TAPD paling lambat akhir bulan agustus tahun berikutnya yang dimana perda tentang laporan pertanggunjawaban pelaksanaan APBD tersebut telah ditetapkan.

Dalam menyelenggarakan pemerintahan di daerah pemda perlu membuat atau menyusun laporan terkait dengan pertanggungjawaban kinerja, dimana salah satu bentuk laporannya adalah Laporan Akuntabilitas Kinerja Instansi Pemerintah (LAKIP) yang telah diatur dalam Instruksi Presiden Nomor 7 Tahun 1999. Laporan Akuntabilitas Kinerja Instansi Pemerintah (LAKIP) merupakan laporan yang berisikan akuntabilitas dan kinerja dari suatu instansi pemerintah. Setelah LAKIP disusun, instansi terkait wajib mengirimkan laporan tersebut kepada KemenPANRB yang selanjutnya akan dilakukan analisis seluruh LAKIP dan mengevaluasi laporan tersebut (Afriyanti dkk., 2015). Setelah proses pelaksanaan evaluasi selesai secara keseluruhan, KemenPAN-RB akan memberikan peringkat nilai dengan sebutan AA, A, B, CC, C, dan D yang rincian interpretasi dan karakteristik instansinya.

Pemerintah Kabupaten Tabanan telah berupaya secara maksimal dalam melaksanakan pembangunan di berbagai bidang dalam rangka pencapaian sasaran RPJMD Semesta Berencana Kabupaten Tabanan tahun 2016-2021, dimana hal tersebut dapat dilihat dari Peraturan Bupati Nomor 74 Tahun 2017 Tentang Perubahan Atas Peraturan Bupati Nomor 44A Tahun 2016 Tentang Indikator Kinerja Utama (IKU) Pemerintah Kabupaten Tabanan Tahun 2016-2021.

Hal penting yang perlu dilakukan dalam penyusunan laporan kinerja adalah pengukuran kinerja dan evaluasi serta pengungkapan secara memadai hasil analisis 
terhadap pengukuran kinerja tersebut. Pengukuran kinerja dilakukan dengan cara membandingkan antara target pencapaian indikator sasaran yang telah ditetapkan dalam perjanjian kinerja dengan realisasinya. Hal tersebut tercermin pada misi ke lima dengan sasaran meningkatkan kualitas SDM dan akuntabilitas instansi pemerintah pada indikator sasaran yakni Nilai Sistem Akuntabilitas Kinerja Instansi Pemerintah (SAKIP).

Tabel 1.

Evaluasi Akuntabilitas Kinerja Instansi Pemerintah (AKIP)

\begin{tabular}{|c|c|c|c|}
\hline No. & Kategori & Nilai Angka & Interpretasi \\
\hline 1. & AA & $>90-100$ & Sangat Memuaskan. \\
\hline 2. & A & $>80-90$ & $\begin{array}{l}\text { Memuaskan, Memimpin perubahan, berkinerja tinggi, dan } \\
\text { sangat akuntabel. }\end{array}$ \\
\hline 3. & BB & $>70-80$ & $\begin{array}{l}\text { Sangat Baik, Akuntabel, berkinerja baik, memiliki sistem } \\
\text { manajemen kinerja yang andal. }\end{array}$ \\
\hline 4. & B & $>60-70$ & $\begin{array}{l}\text { Baik, Akuntabilitas kinerjanya sudah baik, memiliki sistem } \\
\text { yang dapat digunakan untuk manajemen kinerja, dan perlu } \\
\text { sedikit perbaikan. }\end{array}$ \\
\hline 5. & $\mathrm{CC}$ & $>50-60$ & $\begin{array}{l}\text { Cukup (Memadai), Akuntabilitas kinerjanya cukup baik, } \\
\text { taat kebijakan, memiliki sistem yang dapat digunakan untuk } \\
\text { memproduksi informasi kinerja untuk pertanggungjawaban, } \\
\text { perlu banyak perbaikan tidak mendasar. }\end{array}$ \\
\hline 6. & $\mathrm{C}$ & $>30-50$ & $\begin{array}{l}\text { Kurang, Sistem dan tatanan kurang dapat diandalkan, } \\
\text { memiliki sistem untuk manajemen kinerja tapi perlu banyak } \\
\text { perbaikan minor dan perbaikan yang mendasar. }\end{array}$ \\
\hline 7. & $\mathrm{D}$ & $0-30$ & $\begin{array}{l}\text { Sangat Kurang, Sistem dan tatanan tidak dapat diandalkan } \\
\text { untuk penerapan manajemen kinerja, perlu banyak perbaikan, } \\
\text { sebagian perubahan yang sangat mendasar. }\end{array}$ \\
\hline
\end{tabular}

Sumber: Permen PAN-RB, 2015

Menurut Azwar Abubakar, SAKIP adalah integrasi dari sistem perencanaan, sistem penganggaran dan sistem pelaporan kinerja yang selaras dengan pelaksanaan sistem akuntabilitas keuangan. Dalam hal ini, setiap organisasi diwajibkan mencatat dan melaporkan setiap penggunaan keuangan negara serta kesesuaiannya dengan ketentuan yang berlaku. Menurutnya, jika akuntabilitas keuangan hasilnya berupa laporan keuangan, akan tetapi produk akhir atau hasil dari SAKIP adalah berupa LAKIP yang menggambarkan kinerja yang telah dicapai oleh suatu instansi pemerintah atas pelaksanaan program dan kegiatan yang dibiayai oleh APBN/APBD.

Indikator sasaran strategis Nilai SAKIP Pemerintah Kabupaten Tabanan pada tahun 2014 dan 2015 terealisasi dengan predikat C yang artinya Cukup. Pada tahun 2016 menetapkan target untuk memperoleh predikat CC dan terealisasi melampaui target dengan predikat B dengan nilai 60,07 persen serta memiliki tingkat capaian 100 persen. Sedangkan di tahun 2017 ditargetkan memperoleh predikat B dan terealisasi dengan mendapat predikat $\mathrm{B}$ dengan sedikit meningkat dari tahun sebelumnya yaitu 62,47 persen dengan tingkat capaian 100 persen. Pada tahun 2018 Nilai SAKIP Pemerintah Kabupaten Tabanan ditargetkan memperoleh predikat A dan terealisasi mendapatkan predikat B dengan nilai sedikit meningkat dari tahun 
sebelumnya yaitu 63,33 persen dengan tingkat capaian mencapai 79 persen menurun dibandingkan tahun sebelumnya.

Dari hasil data diatas dapat dikatakan bahwa pemerintah daerah Kabupaten Tabanan selama lima tahun terakhir telah mampu memperoleh nilai SAKIP dengan predikat B, walaupun pada tahun 2014 dan 2015 memperoleh nilai SAKIP dengan predikat $\mathrm{C}$. Hal tersebut berarti bahwa akuntabilitas kinerja instansi pemerintahnya sudah baik, memiliki sistem yang dapat digunakan untuk manajemen kinerja, dan perlu sedikit perbaikan yang harus dilakukan oleh pemerintah Kabupaten Tabanan. Tabel berikut menunjukkan data hasil evaluasi Akuntabilitas Kinerja Instansi Pemerintah (AKIP) Kabupaten Tabanan Tahun 2014-2018.

Tabel 2.

Data Hasil Evaluasi AKIP Kabupaten Tabanan Tahun 2012-2015

\begin{tabular}{|c|c|c|c|c|c|c|c|}
\hline \multirow[t]{2}{*}{ No. } & \multirow{2}{*}{ Indikator Kinerja } & \multicolumn{3}{|c|}{$\begin{array}{l}\text { Realisasi Tahun } \\
\text { Sebelumnya }\end{array}$} & \multicolumn{3}{|c|}{ Tahun 2015} \\
\hline & & 2012 & 2013 & 2014 & Target & Realisasi & $\%$ \\
\hline 1. & \begin{tabular}{lr}
\multicolumn{2}{c}{ Hasil penilaian Sistem } \\
Akuntabilitas & Kinerja \\
Instansi & Pemerintah \\
(SAKIP) & Kabupaten \\
Tabanan & \\
\end{tabular} & Cukup & Cukup & Cukup & Cukup & Cukup & $100 \%$ \\
\hline
\end{tabular}

Tabel 2. memberikan gambaran untuk kedepannya mengingat akan disusunnya RPJMD yang baru untuk periode 2016-2021. Pemerintah daerah Kabupaten Tabanan berupaya untuk menyerap aspirasi dari bawah melalui musrenbang kecamatan sampai ke musrenbang kabupaten, sehingga dapat diidentifikasi permasalahan dan target-target pembangunan yang ingin dicapai pada periode 5 tahun kedepan sehingga dapat disusun kebijakan dan program strategis sebagai prioritas pembangunan. Selain itu juga diperlukan penyelarasan yang lebih intens di dalam penjabaran RPJMD itu sendiri ke dalam Renstra SKPD sehingga setiap tahunnya dapat dijalankan dengan baik yang dibarengi dengan capaian kinerja yang lebih baik lagi.

Tabel 3.

Data Hasil Evaluasi AKIP Kabupaten Tabanan Tahun 2016-2017

\begin{tabular}{llcccc}
\hline No. & \multicolumn{1}{c}{ Komponen } & Bobot & $\mathbf{2 0 1 6}$ & $\mathbf{2 0 1 7}$ & $\begin{array}{c}\text { Nilai Nilai } \\
\text { Terhadap } \\
\text { Bobot Th } \\
\mathbf{2 0 1 7}\end{array}$ \\
\hline 1. & Perencanaan Kinerja & 30 & 19,59 & 21,42 & $71,40 \%$ \\
2. & Pengukuran Kinerja & 25 & 11,75 & 12,9 & $51,60 \%$ \\
3. & Pelaporan Kinerja & 15 & 9,69 & 10,17 & $67,80 \%$ \\
4. & Evaluasi Kinerja & 10 & 5,85 & 5,15 & $51,50 \%$ \\
5. & Capaian Kinerja & 20 & 13,19 & 12,85 & $64,25 \%$ \\
& $\quad$ Nilai Hasil Evaluasi & $\mathbf{1 0 0}$ & $\mathbf{6 0 , 0 7}$ & $\mathbf{6 2 , 4 9}$ & \\
\hline
\end{tabular}

Sumber: Laporan Kinerja Instansi Pemerintah Kabupaten Tabanan, 2017 
Tabel 3. menunjukkan data tentang hasil evaluasi AKIP Kabupaten Tabanan tahun 2016 dan 2017, yang dimana data hasil evaluasi AKIP Kabupaten Tabanan pada tahun 2016 menjelaskan bahwa dari bobot maksimal sebesar 30 persen untuk perencanaan kinerja, pemerintah daerah Kabupaten Tabanan baru mampu mencapai nilai sebesar 19,59 persen atau persentase nilai terhadap bobotnya adalah sebesar 65,30 persen. Komponen berikutnya adalah pengukuran kinerja dengan bobot maksimal sebesar 25 persen, pemerintah daerah Kabupaten Tabanan baru mampu mencapai nilai sebesar 11,75 persen atau persentase nilai terhadap bobotnya adalah sebesar 47 persen. Komponen yang ketiga adalah pelaporan kinerja dengan bobot maksimal sebesar 15 persen, yang dimana pemerintah daerah Kabupaten Tabanan baru mampu mencapai nilai sebesar 9,69 persen atau persentase nilai terhadap bobotnya adalah sebesar 64,60 persen. Komponen berikutnya adalah evaluasi kinerja dengan bobot maksimal sebesar 10 persen, pemerintah daerah Kabupaten Tabanan baru mampu mencapai nilai sebesar 5,85 persen atau persentase nilai terhadap bobotnya adalah sebesar 58,50 persen. Komponen yang terakhir atau kelima adalah capaian kinerja dengan bobot maksimal sebesar 20 persen, yang dimana pemerintah daerah Kabupaten Tabanan baru mampu mencapai nilai sebesar 13,19 persen atau persentase nilai terhadap bobotnya adalah sebesar 65,95 persen.

Data berikutnya adalah hasil evaluasi AKIP Kabupaten Tabanan tahun 2017 yang menjelaskan bahwa dari bobot maksimal sebesar 30 persen untuk perencanaan kinerja, pemerintah daerah Kabupaten Tabanan baru mampu mencapai nilai sebesar 21,42 persen atau persentase nilai terhadap bobotnya adalah sebesar 71,40 persen. Komponen berikutnya adalah pengukuran kinerja dengan bobot maksimal sebesar 25 persen, pemerintah daerah Kabupaten Tabanan baru mampu mencapai nilai sebesar 12,90 persen atau persentase nilai terhadap bobotnya adalah sebesar 51,60 persen. Komponen yang ketiga adalah pelaporan kinerja dengan bobot maksimal sebesar 15 persen, yang dimana pemerintah daerah Kabupaten Tabanan baru mampu mencapai nilai sebesar 10,17 persen atau persentase nilai terhadap bobotnya adalah sebesar 67,80 persen. Komponen berikutnya adalah evaluasi kinerja dengan bobot maksimal sebesar 10 persen, pemerintah daerah Kabupaten Tabanan baru mampu mencapai nilai sebesar 5,15 persen atau persentase nilai terhadap bobotnya adalah sebesar 51,50 persen. Komponen yang terakhir atau kelima adalah capaian kinerja dengan bobot maksimal sebesar 20 persen, yang dimana pemerintah daerah Kabupaten Tabanan baru mampu mencapai nilai sebesar 12,85 persen atau persentase nilai terhadap bobotnya adalah sebesar 64,25 persen.

Tabel 4. menunjukkan data tentang hasil evaluasi AKIP Kabupaten Tabanan tahun 2016 dan 2017, yang dimana data hasil evaluasi AKIP Kabupaten Tabanan pada tahun 2017 sudah dibahas pada tabel 3. dan data berikutnya adalah data hasil evaluasi AKIP Kabupaten Tabanan tahun 2018 yang menjelaskan bahwa dari bobot maksimal sebesar 30 persen untuk perencanaan kinerja, pemerintah daerah Kabupaten Tabanan baru mampu mencapai nilai sebesar 22,24 persen atau persentase nilai terhadap bobotnya adalah sebesar 74,13 persen. Komponen berikutnya adalah pengukuran kinerja dengan bobot maksimal sebesar 25 persen, pemerintah daerah Kabupaten Tabanan baru mampu mencapai nilai sebesar 14,36 persen atau persentase nilai terhadap bobotnya adalah sebesar 57,44 persen. Komponen yang ketiga adalah pelaporan kinerja dengan bobot maksimal sebesar 
15 persen, yang dimana pemerintah daerah Kabupaten Tabanan baru mampu mencapai nilai sebesar 10,31 persen atau persentase nilai terhadap bobotnya adalah sebesar 68,73 persen. Komponen berikutnya adalah evaluasi kinerja dengan bobot maksimal sebesar 10 persen, pemerintah daerah Kabupaten Tabanan baru mampu mencapai nilai sebesar 6,01 persen atau persentase nilai terhadap bobotnya adalah sebesar 60,10 persen. Komponen yang terakhir atau kelima adalah capaian kinerja dengan bobot maksimal sebesar 20 persen, yang dimana pemerintah daerah Kabupaten Tabanan baru mampu mencapai nilai sebesar 10,41 persen atau persentase nilai terhadap bobotnya adalah sebesar 52,05 persen.

Tabel 4.

Data Hasil Evaluasi AKIP Kabupaten Tabanan Tahun 2017-2018

\begin{tabular}{|c|c|c|c|c|c|}
\hline \multirow[b]{2}{*}{ No. } & \multirow{2}{*}{ Komponen } & \multirow[b]{2}{*}{ Bobot } & \multicolumn{2}{|c|}{ Nilai } & \multirow{2}{*}{$\begin{array}{c}\% \text { Nilai } \\
\text { Terhadap } \\
\text { Bobot Th } \\
2018\end{array}$} \\
\hline & & & 2017 & 2018 & \\
\hline 1. & Perencanaan Kinerja & 30 & 21,42 & 22,24 & $74,13 \%$ \\
\hline 2. & Pengukuran Kinerja & 25 & 12,9 & 14,36 & $57,44 \%$ \\
\hline 3. & Pelaporan Kinerja & 15 & 10,17 & 10,31 & $68,73 \%$ \\
\hline 4. & Evaluasi Kinerja & 10 & 5,15 & 6,01 & $60,10 \%$ \\
\hline 5. & Capaian Kinerja & 20 & 12,85 & 10,41 & $52,05 \%$ \\
\hline & Nilai Hasil Evaluasi & 100 & 62,49 & 63,33 & \\
\hline
\end{tabular}

Sumber: Laporan Kinerja Instansi Pemerintah Kabupaten Tabanan, 2018

Berdasarkan sumber berita pt-palembang.go.id (2019) disebutkan bahwa Laporan Realisasi Anggaran meberikan gambaran perbandingan antara Daftar Isian Pelaksanaan Anggaran (DIPA) dengan realisasinya, yang meliputi unsur-unsur pendapatan dan belanja dalam tahun yang bersangkutan. Berikut ini merupakan tabel perbandingan antara anggaran dan realisasi yang meliputi unsur-unsur pendapatan dan belanja pemerintah daerah Kabupaten Tabanan selama lima tahun terakhir yakni:

Tabel 5.

Perbandingan antara Anggaran dan Realisasi Pendapatan Daerah Kabupaten Tabanan Tahun 2014-2018

\begin{tabular}{|c|c|c|c|}
\hline \multirow{2}{*}{ Tahun } & \multicolumn{2}{|c|}{ Pendapatan Daerah } & \multirow{2}{*}{ Selisih } \\
\hline & Anggaran & Realisasi & \\
\hline 2014 & 1.328 .610 .781 .308 & 1.367 .063 .683 .393 & 38.452 .902 .085 \\
\hline 2015 & 1.598.653.208.335 & 1.615 .933 .308 .429 & 17.280 .100 .094 \\
\hline 2016 & 1.914 .766 .565 .899 & 1.794 .601 .450 .264 & $(120.165 .115 .635)$ \\
\hline 2017 & 1.913 .540 .384 .115 & 1.871 .864 .102 .726 & $(41.676 .281 .389)$ \\
\hline 2018 & 1.948 .668 .063 .171 & 1.862.277.203.959 & $(86.390 .859 .212)$ \\
\hline
\end{tabular}

Sumber: Laporan Realisasi Anggaran Pemda Kab. Tabanan diolah, 2019 
Tabel 5. menyajikan data mengenai perbandingan antara anggaran dan realisasi pendapatan daerah di Kabupaten Tabanan pada tahun 2014-2018. Berdasarkan tabel tersebut kita dapat mengetahui bahwa pada tahun 2014 dan 2015 realisasi pendapatan daerah di Kabupaten Tabanan lebih besar dibandingkan anggarannya, namun pada tahun berikutnya yaitu tahun 2016 hingga 2018 realisasi pendapatan daerah di Kabupaten Tabanan lebih kecil dibandingkan anggarannya. Hal tersebut dapat mencerminkan bagaimana kinerja pemerintah daerah di Kabupaten Tabanan dalam menggali potensi atau sumber-sumber pendapatan yang dimiliki oleh daerah.

Pada tahun 2014 dan 2015 realisasi pendapatan daerah di Kabupaten Tabanan lebih besar dibandingkan anggarannya, yang dimana hal tersebut mencerminkan bahwa kinerja pemerintahnya sudah mampu melampaui target yang telah dianggarkan, sedangkan pada tahun 2016 hingga 2018 realisasi pendapatan daerah di Kabupaten Tabanan lebih kecil dibandingkan anggarannya, yang dimana hal tersebut mencerminkan bahwa kinerja pemerintahnya belum mampu memenuhi target yang telah dianggarkan.

Tabel 6.

Perbandingan antara Anggaran dan Realisasi Belanja Daerah Kabupaten Tabanan Tahun 2014-2018

\begin{tabular}{cccc}
\hline \multirow{2}{*}{ Tahun } & \multicolumn{2}{c}{ Belanja Daerah } & \multirow{2}{*}{ Selisih } \\
\cline { 2 - 3 } & Anggaran & Realisasi & \\
\hline 2014 & 1.408 .945 .479 .690 & 1.326 .511 .899 .193 & 82.433 .580 .497 \\
2015 & 1.714 .702 .582 .123 & 1.586 .227 .841 .183 & 128.474 .740 .940 \\
2016 & 2.060 .891 .636 .640 & 1.873 .464 .986 .623 & 187.426 .650 .017 \\
2017 & 2.184 .423 .902 .722 & 1.861 .962 .379 .735 & 322.461 .522 .987 \\
2018 & 1.972 .107 .225 .602 & 1.667 .272 .145 .950 & 304.835 .079 .652 \\
\hline
\end{tabular}

Sumber: Laporan Realisasi Anggaran Pemda Kab. Tabanan diolah, 2019

Tabel 6. menyajikan data mengenai perbandingan antara anggaran dan realisasi belanja daerah di Kabupaten Tabanan pada tahun 2014-2018. Berdasarkan tabel tersebut kita dapat mengetahui bahwa dalam lima tahun terakhir yakni dari tahun 2014 hingga 2018 realisasi belanja daerah di Kabupaten Tabanan lebih kecil dibandingkan apa yang telah anggaran. Hal tersebut mencerminkan bagaimana kinerja pemerintah daerah di Kabupaten Tabanan dalam mengalokasikan belanja guna mendanai urusan pemerintah daerah yang besarannya telah ditetapkan sesuai dengan peraturan perundang-undangan.

Dalam kurun waktu lima tahun terakhir yakni dari tahun 2014 hingga 2018 realisasi belanja daerah di Kabupaten Tabanan lebih kecil dibandingkan anggarannya, yang dimana hal tersebut berarti menguntungkan dan menunjukkan bahwa kinerja pemerintah daerah Kabupaten Tabanan sudah mampu melakukan efisiensi belanja apabila dilihat dari efisiensi belanja daerah.

Implikasi hasil penelitian teoretisnya adalah memberikan pengertian yang jelas kepada para akademisi tentang materi manajemen keuangan sektor publik berupa bukti empiris dalam pengembangan ilmu pengetahuan manajemen keuangan pemerintah daerah, sedangkan implikasi hasil penelitian secara praktisnya adalah tentang manajemen keuangan pemerintah daerah di Kabupaten 
Tabanan yang dimana pengelolaan keuangan daerah dimulai dari proses penyusunan, pelaksanaan hingga pertanggungjawaban pelaksanaan APBD di Kabupaten Tabanan. Dalam menyelenggarakan pemerintahan di daerah pemda perlu membuat atau menyusun laporan terkait dengan pertanggungjawaban kinerja, dimana salah satu bentuk laporannya adalah Laporan Akuntabilitas Kinerja Instansi Pemerintah (LAKIP). Laporan Realisasi Anggaran meberikan gambaran perbandingan antara Daftar Isian Pelaksanaan Anggaran (DIPA) dengan realisasinya, yang meliputi unsur-unsur pendapatan dan belanja dalam tahun yang bersangkutan.

\section{SIMPULAN}

Berdasarkan hasil analisis dan pembahasan yang telah dipaparkan sebelumnya maka kesimpulan yang dapat diambil adalah manajemen keuangan pemerintah daerah Kabupaten Tabanan telah mengacu kepada Permendagri Nomor 13 Tahun 2006 Tentang Pedoman Pengelolaan Keuangan Daerah yang dimulai dari proses penyusunan (perencanaan), pelaksanaan (penatausahaan) hingga pertanggungjawaban pelaksanaan (pelaporan) APBD Kabupaten Tabanan. Laporan kinerja instansi pemerintah daerah di Kabupaten Tabanan dalam mengelola keuangan daerahnya selama lima tahun terakhir jika di rata-ratakan pemda Kabupaten Tabanan telah memperoleh predikat B, walaupun pada tahun 2014 dan 2015 memperoleh nilai SAKIP dengan predikat C. Laporan kinerja instansi pemerintah daerah tersebut memiliki beberapa komponen penilaian yakni dimulai dari perencanaan, pengukuran, pelaporan, evaluasi, dan capaian kinerja yang dimana komponen tersebut mempunyai bobotnya masing-masing tergantung dari yang paling penting. Nilai atau persentase nilai terhadap bobot yang dicapai oleh pemerintah daerah setiap tahunnya mengacu pada masing-masing bobot dalam komponen dari laporan kinerja instansi pemerintah daerah tersebut.

Selain itu, perbandingan antara anggaran dan realisasi pendapatan daerah terhadap kinerja pemerintah daerah di Kabupaten Tabanan menunjukkan bahwa apabila anggaran lebih kecil dibandingkan realisasinya yang dimana selisih tersebut tersebut dapat menjadi sumber-sumber SiLPA (Sisa Lebih Perhitungan Anggaran) untuk tahun berikutnya yang digunakan untuk pembiayaan investasi dalam APBD dan selisih tersebut juga mencerminkan bahwa kinerja pemerintahnya sudah mampu mencapai target yang telah dianggarkan, sedangkan apabila anggarannya lebih besar dibandingkan realisasinya yang disebabkan oleh beberapa komponen yang pada tahun bersangkutan realisasinya tidak mencapai apa yang telah dianggarkan dan hal tersebut juga mencerminkan bahwa kinerja pemerintahnya belum mampu memenuhi target yang telah dianggarkan. Apabila dilihat dari segi belanja yang dalam kurun waktu lima tahun terakhir menunjukkan bahwa realisasi belanja daerahnya lebih kecil dibandingkan anggarannya yang dimana selisih tersebut dapat menjadi sumber-sumber SiLPA (Sisa Lebih Perhitungan Anggaran) untuk tahun berikutnya yang digunakan untuk pembiayaan investasi dalam APBD dan hal tersebut berarti menguntungkan serta menunjukkan bahwa kinerja pemerintah daerah Kabupaten Tabanan sudah mampu melakukan efisiensi belanja apabila dilihat dari efisiensi belanja daerah. 
Berdasarkan hasil penelitian dan simpulan diatas maka saran yang dapat diberikan adalah penelitian ini dapat menjadi bahan masukan bagi pemerintah daerah Kabupaten Tabanan dalam melakukan manajemen keuangan daerahnya agar dapat meningkatkan kinerja pemerintahannya. Bagi peneliti selanjutnya, saran yang dapat diberikan adalah sebaiknya dalam melakukan penelitian yang serupa diharapkan untuk tidak melakukan penelitian pada periode yang bersamaan dan dapat menggunakan lokasi yang berbeda pula.

\section{REFERENSI}

Afriyanti, D., Sabanu, H. G., \& Noor, F. (2015). Penilaian Indeks Akuntabilitas Instansi Pemerintah. Jurnal Tata Kelola \& Akuntabilitas Keuangan Negara, 1(1), 21-42. https://doi.org/10.28986/jtaken.v1i1.10.

Andirfa, M., Basri, H., dan Majid, M., S., A. (2016). Pengaruh Belanja Modal, Dana Perimbangan dan Pendapatan Asli Daerah terhadap Kinerja Keuangan Kabupaten dan Kota di Provinsi Aceh. Jurnal Magister Akuntansi Prigram Pascasarjana Universitas Syiah Kuala Banda Aceh, 5(3), 30-38. Retrieved from http://www.jurnal.unsyiah.ac.id/JAA/article/download/ 4523/3898.

Antari, N., P., G., S., dan Sedana, I., B., P. (2018). Pengaruh Pendapatan Asli Daerah dan Belanja Modal terhadap Kinerja Keuangan Pemerintah Daerah. E- Jurnal Manajemen Unud, 7(2), 1080-1110.

Armaja, Ibrahim, R., dan A. (2015). Pengaruh Kekayaan Daerah, Dana Perimbangan dan Belanja Daerah Terhadap Kinerja Keuangan. Jurnal Perspektif Ekonomi Darussalam, 3(2), 168-181.

Bambang, J., and Farhan, M. (2016). Key Success Factors of Local Revenue Toward City And District Government Performance in Yogyakarta. Journal of Muhammadiyah University, 1-19.

Budianto dan Alexander, S., W. (2016). Pengaruh PAD dan Dana Perimbangan terhadap Kinerja Keuangan Pemerintah Kabupaten/Kota di Provinsi Sulawesi Utara. Jurnal Riset Ekonomi, Manajemen, Bisnis Dan Akuntansi, 4(4), 844851.

Eton, M., Arinaitwe, P., Mwosi, F., \& Ogwel, B. P. (2019). Participatory Budgeting In Local Governments The Case Of Kabale District Local Government, Uganda. International Journal of Emerging Technology and Innovative Engineering, 5(8), 602-613.

Fitrie, S. (2008). Pengelolaan Keuangan daerah Perspektif Permendagri No. 13 Tahun 2006 Pada Pemerintah Kota Binjai.

Halim, A. (2007). Akuntansi Keuangan Daerah. Jakarta: Salemba Empat. 
Halim, A. (2016). Manajemen Keuangan Sektor Publik. Jakarta: Salemba Empat.

Hendawati, H., Komarasakti, D., and Ansori, S. (2018). The Effect of Capital Cost and General Allocation Fund To The Regional Financial Independence in Bandung City Government. The International Journal Of Business Review (The Jobs Review), 18(2), 155-163.

Ichsan, H., Said, D., and Fattah., S. (2018). The Effect Of Intellectual Capital Disclosures On Local Government Financial Performance And The Intergovernmental Revenue As The Moderating Variabel. Journal of Research in Business and Management, 6(5), 46-53.

Kondo, E., M. (2015). The Effect Of Revenue Enhancement Strategies On Financial Performance Of Kenya Revenue Authority. Journal of Nairobi University, 1-51.

Kuntari, Y., Chariri, A., \& Prabowo, T. J. W. (2019). Capital expenditure of local governments. Academy of Accounting and Financial Studies Journal, 23(1), $1-13$.

Kurniawati, S., Busaini, H., and M., Rr., S., P. (2017). Determinants Of Financial Performance: Study Of Local Governments In West Nusa Tenggara. Journal of Mataram University, 1536-1560.

Mahmudi. (2010). Manajemen Keuangan Daerah. Jakarta: Erlangga.

Manopo, Novlie ; Rotinsulu, Debby Ch ; Murni, S. (2015). Analisis Efisiensi dan Efektivitas Pengelolaan Keuangan Daerah Kabupaten Minahasa Tenggara. Jurnal Pembangunan Ekonomi Dan Keuangan Daerah, 17(2), 1-14. https://doi.org/https://doi.org/10.35794/jpekd.10249.17.2.2015.

Mardiasmo. (2009). Akuntansi Sektor Publik. Yogyakarta: Andi.

Mohammed, A., and S. (2015). Expenditure and Internally Generated Revenue Relationship: An Analysis of Local Governments in Adamawa State, Nigeria. Journal of Arts Science \& Commerce, 6(3), 67-77.

Mutya, T., \& Josephine, A. (2018). Financial Management a Wheel to Financial Performance of Local Governments in Uganda: A Case Study of Tororo Municipal Council. Journal of Business \& Financial Affairs, 07(02). https://doi.org/10.4172/2167-0234.1000330.

Nazir, M. (1988). Metode Penelitian. Jakarta: Ghalia Indonesia.

Oktaviana, I., and Husnan, L. H. (2017). The Effect of Fiscal Decentralization, 
Fiscal Stress And Intergovernmental Revenue on The Financial Performance of Local Government. Journal E-Proceeding STIE Mandala Jember, 553571.

Rahman, A. J., Soelistyo, A., \& Hadi, S. (2016). Pengaruh Investasi, Pengeluaran Pemerintah Dan Tenaga Kerja Terhadap Pdrb Kabupaten/Kota Di Propinsi Banten Tahun 2010-2014. Jurnal Ekonomi Pembangunan, 14(02), 112-121. https://doi.org/10.22219/jep.v14i1.3890.

Ritonga, I. T. (2014). Developing a measure of local government's financial condition. Journal of Indonesian Economy and Business, 29(2), 142-164. https://doi.org/10.3389/fphys.2017.01021.

Rondonuwu, R., H., Tinangon, J., J., dan Budiarso, N. (2015). Analisis Efisiensi dan Efektivitas Pengelolaan Keuangan Daerah pada Dinas Pendapatan Daerah Kabupaten Minahasa. Jurnal Riset Ekonomi, Manajemen, Bisnis Dan Akuntansi, 3(4), 23-32.

Sari, N. M. D. P., \& Mustanda, I. K. (2019). Pengaruh Ukuran Pemerintah Daerah, Pendapatan Asli Daerah Dan Belanja Modal Terhadap Kinerja Keuangan Pemerintah Daerah. 8(8), 4759-4787.

Sebastian and Cahyo, H. (2016). Analysis of Economic Performance as the Independence Indicators of Government in East Java Province. Review of Integrative Business \& Economics Research, 5(2), 272-285.

Sumawan, I., W., dan Sukarta, I., M. (2016). Faktor-Faktor yang Berpengaruh pada kinerja Belanja Pemerintah Kabupaten/Kota di Provinsi Bali. E-Jurnal Akuntansi Universitas Udayana, 14(3), 1727-1754. https://doi.org/10.3997/2214-4609.201404048.

Sunaryo, K., and Ghofar, A. (2015). Characteristics Local Government and Government Performance: An Empirical Examination of The Local Government in Indonesia. Journal Buletin Ekonomi, 13(2), 139-270.

Taras, T., dan Artini, L., G., S. (2017). Analisis Pendapatan Asli Daerah (PAD) dalam Upaya Pelaksanaan Otonomi Daerah di Kabupaten Badung Bali. EJurnal Manajemen Uhud, 6(5), 2360-2387.

Tarmizi, R., Khairudin, and Fransisca, F. (2015). The Influence Of Prosperity And Financial Performance With Respect To Equalization Funds Of The Government District/City In All Southern Sumatra Regions. Journal of Bandar Lampung University, 66-72.

Usman, S. A., Yusufari, M. Y., Hamza, A., \& Abdullahi (Ph.D.), S. R. (2016). The Effect of BudgetIng and Budgetary Control in Local Government 
I Kadek Arta Wijaya Santosa, Manajemen Keuangan Pemerintah...

Administration of Nigeria. European Journal of Business and Management Www.Iiste.Org ISSN, 8(22), 135-140. Retrieved from www.iiste.org.

Wardhani, R., Rossieta, H., \& Martani, D. (2017). Good governance and the impact of government spending on performance of local government in Indonesia. Int. J. of Public Sector Performance Management, 3(1). 